\title{
Effect of carbide waste on the properties of Makurdi shale and burnt bricks made from the admixtures
}

\author{
Agbede, I. O, and Joel, M \\ Department of Civil Engineering, University of Agriculture, Makurdi, Nigeria. \\ femiagbede2002@yahoo.com and manassehjoel@yahoo.com
}

\begin{abstract}
A study was undertaken to investigate the effects of a byproduct of oxy-acetylene gas welding, carbide waste $(\mathrm{CW})$ on the engineering properties of Makurdi shale blended with 0 to $8 \%$ of $\mathrm{CW}$ for use in brick production. Atterberg limits and specific gravity of shale blended with $\mathrm{CW}$ were determined. Compressive strength and water absorption tests were conducted on triplicate cube specimens of each admixture which were fired to $800{ }^{\circ} \mathrm{C}$. In addition, X-ray fluorescence tests were performed on the shale and $\mathrm{CW}$. Results showed that Makurdi shale comprise mainly of silica and alumina while $\mathrm{CW}$ was essentially calcium oxide. The results suggested that $4 \% \mathrm{CW}$ mix was suitable to stabilize the shale. The study also showed that heat treatment of Makurdi shale and Makurdi shale : CW admixtures yielded bricks of good quality.
\end{abstract}

Keywords: Carbide waste, Makurdi shale, Burnt bricks.

\section{INTRODUCTION}

There are many problem soils which pose a great danger to both building and road construction works. One of them is shale which undergoes volume change with the seasons; a characteristic which makes it to expand when wet and shrink when dry. Thus stabilization becomes necessary to manage such a problem soil.

Lime and cement have been meaningfully used for soil stabilization and improvement (Reids and Brooks, 1999, Basha et al. 2005; Eze-Uzomaka and Agbo, 2010; Joel and Agbede, 2010).

Lopez-Lara et al. (1999) reported that stabilization of expansive clays with lime led to a considerable decrease in the plasticity index and the agglomeration effects of the soil and its contraction and expansion characteristics. The optimum percentage of lime to stabilize the soil was found to be $6 \%$.

It was reported that kaolinites are not very sensitive to lime while montmorillonites are very sensitive because lime works by forming crystallized aluminates, besides modifying the soil, thus constituting truly cement.. Illite is a mineral which hardly reacts with lime. (Lopez-Lara et al. 1999)

The optimum lime content for maximum strength gain in stabilizing soil with lime according to Eades and Grim (1960) is $4-6 \%$ for Kaolinite, about $8 \%$ for Illite and Montmorillonite. Ola (1978) found a linear relationship between the strength of lime-stabilized black cotton soil and lime content (up to $10 \%$ ). Akawwi and Al-Kharabsheh (2002) reported that best result was obtained when $3.5-5 \%$ quicklime by dry weight of soil was used to improve and stabilize expansive soils in Amman, Jordan.

Research carried out in Egypt explored the production of bricks using shale which by itself is unsuitable for brick production. Its potential for brick production in combination with other materials such as sand were also explored and it was reported that bricks of acceptable quality were produced (Glanville, 1992).

Bricks are classified by both the average or minimum compressive strength and the percentage water absorption. According to this classification, minimum compressive strength of bricks should be $3.5 \mathrm{MN} / \mathrm{m}^{2}$ and the water absorption should not exceed $20 \%$. (Brick Development Association, 1974; IS 1077. 1992).

The ASTM C 62 - 97 specification for building bricks sets $20.7 \mathrm{~N} / \mathrm{mm}^{2}, 17.2 \mathrm{~N} / \mathrm{mm}^{2}$ and $10.3 \mathrm{~N} / \mathrm{mm}^{2}$ as the minimum fired compressive strengths for Grade SW (severe weather), Grade MW (moderate weather) and Grade NW (negligible weather) bricks respectively.

The objective of this study was to explore the stabilization of Makurdi shale with carbide waste and examine the properties of bricks made with shale carbide waste admixtures 


\section{MATERIALS AND METHODS}

Shale was obtained from a borrow pit close to Block D hostel, University of Agriculture, Makurdi. Benue State in Nigeria. The trial pit was 1.8 meters deep and excavation was by means of a hoe and digger and the sample was yellowish green in colour. The carbide waste used for the analysis was collected from New Garage in Makurdi where many welders utilize carbide for oxy-acetylene gas welding.

The following tests were performed on the natural soil and the carbide waste-shale admixtures.

Atterberg limits, Grain size analysis, Specific gravity and B.S Heavy compaction. All the tests were performed in accordance with the British Standard specifications. B.S 1377 (1990). X-ray fluorescence analysis was conducted on the shale and carbide waste.

Different percentages of CW $(2,4,6,8$ and 10 of dry weight of soil) was thoroughly mixed with clay and a graded addition of water until approximately the optimum moisture content as determined during compaction. This gave a good moulding consistency and there after molded into brick each measuring $40 \mathrm{~mm} \times 40 \mathrm{~mm} \times 40 \mathrm{~mm}$. Using a caste ion mould cavity and compressed under $15 \mathrm{MN} / \mathrm{m}^{2}$ pressure using a compression machine. The moulded brick was extruded by loosening the mold and carefully removing the brick. The brick was cured at room temperature for 12 days prior to burning.

Three bricks were moulded from each admixture. After careful drying and curing at room temperature, the bricks were subsequently fired in an electric muffle furnace with a rise of $200^{\circ} \mathrm{C} / \mathrm{h}$ and a 4 hour soak at $800^{\circ} \mathrm{C}$.

The compressive strength of each brick was determined in accordance with the Specification of the Standard Organization of Nigeria (SON) as contained in Test for Compressive Strength of Solid Bricks using the Testing Machine.

A $40 \mathrm{~mm}$ square platen was used on the compressive testing machine. Three test cubes were preconditioned by immersion in cold water at room temperature $\left(29{ }^{\circ} \mathrm{C} \pm 2{ }^{\circ} \mathrm{C}\right)$ for 24 hours, removed and all traces of water wiped off, and then stored under moist conditions for 24 hours prior to testing. Each test piece was centrally positioned between the platens of the testing machine, and the load was gradually increased until failure.

The water absorption test was performed by a "24 hour immersion in cold water" as specified by the Standard Organization of Nigeria. Three cubes were preconditioned by drying in a ventilated oven at $10{ }^{\circ} \mathrm{C}$ until it attained constant mass and then cooled to room temperature and weighed to note its initial weight $M_{1}$. The precondition test piece was immersed in cold water at room temperature $\left(29{ }^{\circ} \mathrm{C} \pm 2\right)$ for 24 hours and thereafter removed and any traces of water wiped off. The test piece was then weighed to note its increased weight $M_{2}$. The water absorption, defined as the relative increase in weight, was thus calculated. The test was conducted on three test pieces for each admixture composition.

\section{RESULTS AND DISCUSSION}

Table 1 summarizes the test results of this study. Figure 1 shows the particle size distribution of Makurdi shale while Figure 2 shows the variation of Atterberg limits with carbide waste content. The liquid limit decreased with the increase in carbide waste content, a minimum value of $37 \%$ was attained at $8 \% \mathrm{CW}$. The plastic limit increased from $15 \%$, for the natural shale to an optimum value of $36.4 \%$ at $4 \% \mathrm{CW}$. Plasticity index, a good indicator of swelling potential decreased from $34 \%$ for the natural shale, to $9.3 \%$, at $4 \% \mathrm{CW}$. Beyond this point, it increased to $17.50 \%$ at $6 \% \mathrm{CW}$, then reduced again at $8 \% \mathrm{CW}$.

Table 1. Summary of test results

\begin{tabular}{|c|c|c|c|c|c|c|c|c|c|}
\hline $\begin{array}{l}\text { CW } \\
(\%)\end{array}$ & $\begin{array}{l}\text { LL } \\
(\%)\end{array}$ & $\begin{array}{l}\text { PL } \\
(\%)\end{array}$ & $\begin{array}{l}\mathrm{PI} \\
(\%)\end{array}$ & $\begin{array}{l}\text { LS } \\
(\%)\end{array}$ & $\mathbf{G}_{\mathbf{s}}$ & $\begin{array}{c}\text { MDD } \\
\left(\mathrm{MN} / \mathrm{m}^{3}\right)\end{array}$ & $\begin{array}{l}\text { Optimum m } \\
(\%)\end{array}$ & $\begin{array}{c}\text { Compressive } \\
\text { Strength }\left(\mathrm{MN} / \mathrm{m}^{2}\right)\end{array}$ & $\begin{array}{c}\text { Water } \\
\text { Absorption (\%) }\end{array}$ \\
\hline 0 & 49.0 & 15.0 & 34.0 & 12.8 & 2.69 & 1.69 & 14.9 & 18.8 & 11.2 \\
\hline 2 & 38.0 & 21.8 & 16.2 & 11.4 & 2.50 & 1.63 & 15.0 & 5.2 & 16.4 \\
\hline 4 & 46.4 & 36.4 & 10.0 & 7.1 & 2.36 & 1.65 & 15.0 & 5.5 & 16.5 \\
\hline 6 & 45.0 & 27.5 & 17.5 & 7.9 & 2.41 & 1.67 & 14.4 & 7.3 & 17.8 \\
\hline 8 & 37.9 & 25.0 & 12.9 & 7.9 & 2,40 & 1.80 & 15.5 & 5.9 & 18.7 \\
\hline
\end{tabular}

The shale had a specific gravity of 2.69 , which is within the range for cohesive soils (Bowles, 1984). The specific gravity reduced with increase in the percentage of carbide waste but was constant at 2.4 as from $6 \% \mathrm{CW}$. 


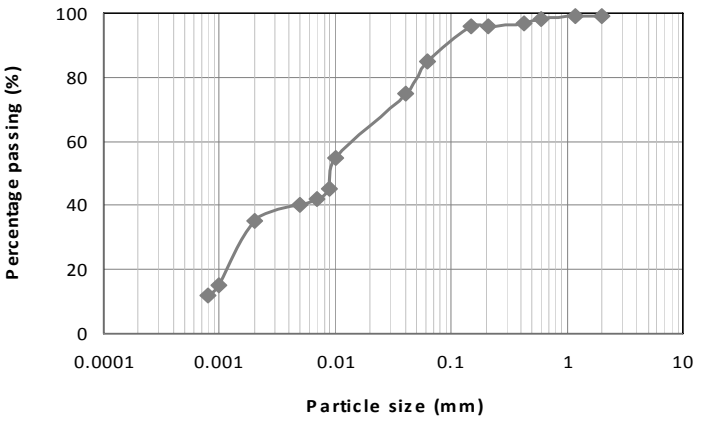

Fig ure 1. Particle size dis tribution of Makurdi S hale.

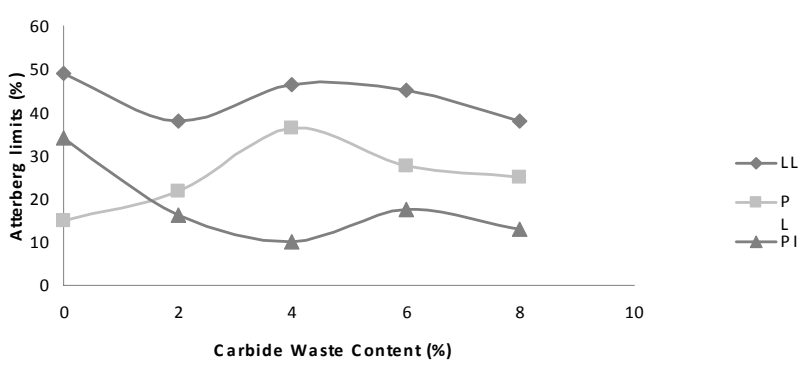

Figure 2. Relationship between Atterberg limits and carbide was te content (\%)

Table 1 showed that the addition of carbide waste adversely affected the compressive strength and water absorption characteristics of the bricks. The bricks made with zero additive can be classified as MW grade according to ASTM C 62 -97 specification. Bricks made with 2 to $8 \% \mathrm{CW}$ had compressive strength of more than $5 \mathrm{~N} / \mathrm{mm}^{2}$, which was specified as the limit for bricks for damp proof courses 1 and 2 by BS 3921 (1985). However, the sudden reduction in the compressive strength of bricks with the addition of carbide waste suggests that very high quality bricks cannot be produced by blending $\mathrm{CW}$ with Makurdi shale.

Makurdi shale was reported by Agbede and Smart (2004) to have illite/smectite mixed clay mineral, which ordinarily disqualifies the use of such an expansive soil for brick production. But it was also reported that when the clay was subjected to heat treatment in the X-ray diffraction study at $600{ }^{\circ} \mathrm{C}$, the expandable illite/smectite layer collapsed to illite. This phenomenon, it would appear was replicated when shale bricks were fired at $800{ }^{\circ} \mathrm{C}$, which gave rise to a very high compressive strength of $18.8 \mathrm{MN} / \mathrm{m}^{2}$. It therefore suggests that heat treatment is a very good method of improving the engineering properties of this problem soil.

Table 2 shows the oxide composition of Makurdi shale and carbide waste. Makurdi shale contained alumina content of $32.4 \%$ which is in the range specified for fireclay $25-45 \%$. The silica content is $44.10 \%$ which is below the value of $55-75 \%$ for fireclay. The iron content of $0.55 \%$ is in the range of $0.5-2.0 \%$ for fireclay.

\section{Table 2. Chemical composition of materials}

\begin{tabular}{|l|l|l|}
\hline Element & $\begin{array}{l}\text { Makurdi } \\
\text { Shale (\%) }\end{array}$ & $\begin{array}{l}\text { Carbide } \\
\text { Waste (\%) }\end{array}$ \\
\hline $\mathrm{SiO}_{2}$ & 44.10 & 2.69 \\
\hline $\mathrm{Al}_{2} \mathrm{O}_{3}$ & 32.38 & 1.78 \\
\hline $\mathrm{Fe}_{2} \mathrm{O}_{3}$ & 0.55 & 0.17 \\
\hline $\mathrm{CaO}$ & 1.30 & 61.41 \\
\hline $\mathrm{MgO}$ & 1.49 & 0.80 \\
\hline $\mathrm{K} 2 \mathrm{O}$ & 0.16 & 0.10 \\
\hline $\mathrm{Na}_{2} \mathrm{O}$ & 0.20 & - \\
\hline $\mathrm{MnO}$ & 0.09 & - \\
\hline $\mathrm{TiO}_{2}$ & 3.06 & - \\
\hline $\mathrm{P}_{2} \mathrm{O}_{5}$ & 4.29 & - \\
\hline $\mathrm{L.O.I}$ & 10.18 & 32.51 \\
\hline
\end{tabular}

\section{CONCLUSION}

The study has shown that addition of carbide waste to Makurdi shale greatly improved its engineering properties. The plasticity index and linear shrinkage attained their minimum values of $10 \%$ and $7 \%$ respectively at $4 \%$ carbide waste. This suggests that $4 \%$ carbide waste can be recommended to stabilize Makurdi shale. The utilization of carbide waste to improve Makurdi shale has the advantage of preventing the pollution of air and ground water.

The compressive strength and water absorption characteristics obtained suggest that good quality bricks can be produced from shale alone and when shale is admixed with carbide waste.

\section{REFERENCES}

Agbede, I. O. and Smart, P. (2004). Mineralogy of 'Igumale' shale in Nigeria. Journal of Scientific and Industrial Studies. 2(2):. $28-37$.

Akawwi, E. and Al-Kharabsheh, A. (2002). Lime stabilization effects on geotechnical properties of expansive soils in Amman, Jordan. Electronic Journal of Geotechnical Engineering. www.ejge.com/2000 ppr0020. 
American Society for Testing Materials (ASTM) (1990). Standard specification for hollow brick (hollow masonry units made from clay or shale) United States of America, ASTM C 652 -89a.

Basha E. A., Hashim, R., Mahmud, H. B. and Muntohar, A. S. (2005). Stabilization of residual soil with rice husk ash and cement. Construction and Building Materials, $19,448-453$

Bowles, J.E. (1984). Physical and geotechnical properties of soils. McGraw-Hill, International Book Company, London.

William, E. and Airey, D (1999), Influence of swelling strain on selected engineering properties of Bringelly shale at southwest region of Sydney, Australia. Electronic Journal of Geotechnical Engineering 4.

British Standards Institution (1985), British standard specification for clay bricks. London, p. 3921.

BS1377 (1990) Methods of testing soils for civil engineering purposes, British standard Institution, London.

Eades,J.L. and Grim, R.E. (1960). The reaction of hydrated lime with pure clay minerals in soil stabilization. U.S. Highway Research Board Bulletin, 262: 51-63.

Eze-Uzomaka, O. J. and Agbo, D. (2010). Suitability of quarry dust as improvement to cement stabilized laterite for road bases. Electronic Journal of Geotechnical Engineering 15(K):1053 - 1066.

Glanville, J. I. (1992). Shale brick production (Egypt). Evaluation Report Prepared for International
Development Research Centre IDRC File 3 - p - 88 1045.

IS 1007,(1992). Indian standard: common burnt clay building bricks-specification. 5th Edition. BIS.New Delhi.

Joel, M. and Agbede, I. O. (2010). Cement stabilization of Igumale shale lime admixtures for use as flexible pavement construction material. Electronic Journal of Geotechnical Engineering, 15, 1661 - 1673.

Lopez-Lara, T and Zepeda-Garrido, and Castario, V. M. (1999). A comparative study of the effectiveness of different additives on the expansion behaviour of clays, Electronic Journal of Geotechnical Engineering Vol.4.

Ola, S.A. (1978) The geology and geotechnical properties of the black cotton soils of north-eastern Nigeria. In Tropical soils of Nigeria in Engineering practice. A.A. Balkema/Rotterdam.131-144.

Reid, J. M. and Brooks, A. H. (1999). Investigation of lime stabilized contaminated soils. Engineering Geology, $53,217-231$.

William, E. and Airey, D (1999), Influence of swelling strain on selected engineering properties of Bringelly shale at southwest region of Sydney, Australia. Electronic Journal of Geotechnical Engineering 4. 